DOI 10.22460/infinity.v7i1.p61-68

\title{
DESIGN OF LEARNING MATERIALS ON LIMIT FUNCTION BASED MATHEMATICAL UNDERSTANDING
}

\author{
Muchamad Subali Noto ${ }^{1}$, Surya Amami Pramuditya ${ }^{2}$, Yudrick Maulana Fiqri ${ }^{3}$ \\ 1,2,3 Universitas Swadaya Gunung Djati, Jl. Perjuangan 1, Cirebon, Indonesia \\ ${ }^{1}$ balimath61@gmail.com, ${ }^{2}$ amamisurya@gmail.com, ${ }^{3}$ bimbingan16@gmail.com
}

Received: January 9, 2018 ; Accepted: February 1, 2018

\begin{abstract}
This study aimed to analyze learning obstacles, designing learning materials based on the material mathematics understanding algebra limit function, determine teacher intervention during the implementation of learning materials and to analyze learning obstacle after the implementation of learning materials. This research is a design research using the form Didactical Design Research. Stages of research conducted: 1) ADP before learning, 2) analysis of metapedadidatik and 3) the retrospective analysis. The instrument used was a matter CMAT (Comprehension Mathematical Ability Test), interview, validation sheet, and documentation guidelines. Research results obtained are: 1) students' difficulties in relating the material prerequisites to limit problems. 2) students can not write properly limit symbol, 3) students can not apply a limit theorem, 4) students are not able to determine the limit value at one point, and 5) students cannot determine the value of the limit at infinity. Learning materials that have been made have validation level of $89.50 \%$ (valid). The response was given when the student intervention, generally in accordance with response prediction so that interventions carried out in accordance with the design that has been made and learning obstacles implemented reduced.
\end{abstract}

Keywords: Didactical Design Research, Learning Obstacle, Limit Functions Algebra, Mathematical Understanding.

\begin{abstract}
Abstrak
Penelitian ini bertujuan untuk menganalisis hambatan belajar siswa, mendesain bahan ajar berbasis pemahaman matematis pada materi limit fungsi aljabar yang valid, mengetahui intervensi guru saat implementasi bahan ajar serta menganalisis hambatan belajar siswa setelah implementasi bahan ajar. Peneitian ini merupakan penelitian desain berupa Didactical Design Research. Tahapan penelitian yang dilakukan yaitu: 1) analisis situasi didaktis sebelum pebelajaran, 2) analisis metapedadidatik dan 3) analisis retrospektif. Instrumen yang digunakan adalah soal TKPM (Tes Kemampuan Pemahaman Matematis), pedoman wawancara, lembar validasi bahan ajar, dan pedoman dokumentasi. Hasil penelitian yang didapatkan adalah: 1) siswa kesulitan dalam mengaitkan materi prasyarat dengan permasalahan limit. 2) siswa tidak dapat menuliskan simbol limit dengan benar, 3) siswa tidak dapat menerapkan teorema limit, 4) siswa tidak dapat menentukan nilai limit di satu titik, dan 5) siswa tidak dapat menentukan nilai limit di tak hingga. Bahan ajar yang telah dibuat memiliki tingkat validasi sebesar $89,50 \%$ dengan kriteria sangat valid. Respon yang diberikan siswa saat intervensi, secara umum sesuai dengan predisi respon sehingga intervensi yang dilakukan sesuai dengan rancangan yang telah dibuat. Setelah bahan ajar diimplementasikan hambatan belajar siswa berkurang/terminimalisir.
\end{abstract}

Kata Kunci: Didactical Design Research, Hambatan Belajar, Limit Fungsi Aljabar, Pemahaman Matematis.

How to Cite: Noto, M. S., Pramuditya, S. A., \& Fiqri, Y. M. (2018). Design of Learning Materials on Limit Function based Mathematical Understanding. Infinity, 7 (1), 61-68. doi:10.22460/infinity.v7i1.p61-68. 


\section{INTRODUCTION}

Mathematics is one of the lessons that characteristics are abstract and difficult. Most students at all levels of education believe that mathematics is a daunting and difficult lesson to learn because it is abstract. Mindset or way of thinking like this that make the students feel pressure to learn mathematics. Math is a subject that is not liked even hated subjects for children in general. According Suhandri (2016), was difficult mathematics learning by students because most students have not been able to connect between the material being studied with the knowledge to use. Therefore, the learning of mathematics is so important, because in the daily life of the students will encounter problems of mathematics where students are required to complete the math problems to master an understanding of mathematical concepts.

Wahyuni and Kharimah (2017) state that the ability of mathematical understanding is an important factor in the study of mathematics and should be owned by the students to be able to solve the problems of mathematics. As said by Ratnasari (2014) the ability of mathematical understanding is the ability to be owned by the students in achieving the goals of learning, where the material presented to students not just rote, but more than that the students should understand the concept of the subject matter itself and how the application of these concepts to solve problems. This is in harmony with Bloom that an understanding not just of the fact, however, with regard to the ability to explain, explain, interpret or ability to grasp the meaning or the meaning of a concept. It can be concluded that the ability of mathematical understanding is one of the important goals in learning, because with control of students' mathematical understanding can develop learning ability in mathematics, students can apply the concepts they have learned to solve simple to complex.

However, the importance of understanding mathematical ability is not fully developed in the process of learning mathematics, in particular, the limit with the subject matter limit algebra functions. Based on the results of preliminary studies conducted by researchers obtained data from student learning in the classroom XI-grade IPA Senior High School in Cirebon based mathematical understanding of the subject of algebraic functions that limit students' average score was 47.53. The average value is still quite low if it is in the interval 1-100. In addition, if the result of mathematical understanding based learning is associated with the chief engineer at the school, it can be said to be the result of students' mathematical understanding based learning in the classroom XI-grade IPA Senior High School in Cirebon yet reached KKM, that are 75 . These results indicate that mathematical understanding based learning outcomes of students at that school is still relatively low.

The material limit function began to study at the senior high school level (SMA) in XI-grade. It is an abstract matter, based on interviews with a math teacher at the school that some students in understanding the material limit function having trouble learning and solving problems limit function. This is in line with Hidayat (2017), the limit function material students have difficulties in calculating the value of the limit function. In determining the limit of a function at a point and at the point of infinity students are still difficult to choose which way is appropriate to solve the problems because it can not examine the forms you see. In addition, students are still difficulties in factoring, multiplying by a factor of opponents, split with the highest rank, and apply the properties of the limit function to find the value of the limit of a function.

Based on the results of preliminary studies, interviews and relevant research it can be concluded that there are difficulties experienced by students in the study material algebra limit 
function. Difficulties and obstacles experienced by students in the study called the learning obstacle. According to Brousseau (2006), learning obstacle is divided into three types of obstacle ontological (mental readiness to learn), didactical obstacle (teaching teachers) and epistemological obstacle (knowledge of students who have limited application context). If you paid attention, learning obstacles/ barriers to learning experienced by students in the study material that is limit function learning obstacle/ barriers to learning that are epistemological (knowledge of students who have limited application context).

Learning materials is very important for teachers and students, because the materials have a major contribution to the success of the learning process is implemented. The usefulness of the actual learning resources cannot be separated from the aim of learning resources that become meaningful. According to Noto, Hartono \& Sundawan (2016) The development of teaching materials must be based to the description of the abilities of the attention to the difficulty/confusion created by the students. Function, purpose, and benefits of learning materials for teachers, among others, is to change the role of a teacher educator as a facilitator, helping students to learn something, and educators will have instructional materials that can assist in the implementation of learning activities. While the function, purpose, and benefits of learning materials for students, among others students, can learn the appropriate speed of each, helping students learn, and learning activities become more attractive. One type of resource is a module.

Module is a teaching material systematically arranged in an easily understood by students according to their level of knowledge and age so that they can learn on their own (independent) with minimal assistance or guidance from educators. By making the design of learning materials developed by learning obstacle is expected that students no longer have significant obstacles during the process of mathematical understanding. Based on the identification of the above problems, the formulation of the problem of this study is as follows.

\section{METHOD}

The research method is a qualitative research and design used Didactical Design Research. According to Cresswell (2012) qualitative research is an approach to building a knowledgebased statement-constructive perspective, perspective-participatory or both. According to Suryadi (2013), study design didactic basically consists of three stages: (1) analysis of the situation didactic before learning that his form is in the form of design didactic Hypothetically including ADP; (2) analysis metapedadidaktik; and (3) analysis of retrosfektif the analysis linking the results of analysis of didactic hypothetical situation with metapedadidaktik analysis results.

Subjects in this study are divided into two, namely the subject of early identification of learning obstacle and the subject of learning materials design implementation. Early identification subject of learning obstacle is the student who has received the material in XIgrade limit algebraic function in KTSP 2006 that XI-grade IPA 1 at one of senior high school in Cirebon and subject-based teaching material design implementation capabilities mathematical understanding on the material limit algebra functions are students who do not get the material limit function, which is in XI-grade IPA 2 in the same school.

Data collection techniques used were tests, interviews, questionnaires (questionnaire), and documentation. The instrument used was a matter CMAT (Comprehension Mathematical 
Ability Test), interview, validation sheet materials, and documentation guidelines. Instruments of test trials used in the form of the ability of understanding mathematical description consist of 8 questions later identified his learning obstacle.To find out the merits of a matter that has been tested then have to do the analysis item, which is to see the validity, reliability, difficulty index, and the distinguishing features of the matter.

Instruments such interview guides for teachers and students. Guidance teacher interview, containing questions about the learning materials used by teachers as well as the difficulties experienced by students when studying algebra limit function. While the student interview guidelines contain students about the difficulties experienced when working on the problems limit function-based algebra and mathematical understanding of the students' instructional materials used in the learning process.

Instruments of expert validation sheet are given to the experts after the design is completed instructional materials. Validation sheet materials used to determine the level of validity of a decent teaching material and whether or not a resource is used. Validator experts chosen are two lecturer of mathematics education Unswagati Cirebon and a senior teacher of mathematics at senior high school.

Instrument documentation in the form of documentation guidelines. Guidance documentation did when researchers conducted a variety of activities associated with the research. Documentation is also used as physical evidence of the activities of researchers. Forms of documentation such as photos and videos when researchers make the learning process in the classroom. Through video, documentation can be analyzed by descriptive prediction of a student's response, by linking the response and anticipation that has been made previously by the student responses that occur when implemented.

\section{RESULTS AND DISCUSSION}

The results will be presented of which include learning obstacle before the implementation of the learning materials, learning materials validation results from three validators, intervention teachers in the implementation of learning materials and analytics learning obstacle after the implementation of learning materials.

\section{Learning Obstacle Pra Implementation of Instructional Materials}

Based on the stages of the research, the authors compile learning materials appropriate learning obstacles found while testing the matter. Based on the previous explanation of the difficulties experienced by students, it appears that the difficulties that occur are of learning obstacle the type epistemology where students have limited knowledge in a particular context. According to Brousseau (2006), to find resistance epistemology one of them by finding common mistakes made repeatedly and are grouped under the concept.

From the analysis of learning obstacle that has been done there is an error, namely 1) the student is not able to associate the material prerequisites to problems limit algebraic function, 2) students can not write symbols limit correctly, 3) students can not apply a limit theorem, 4) students are not able to determine the limit value at one point, and 5) students cannot determine the value of the limit at infinity. Anticipations of the teacher when learning and presented in modules that have been made, is expected to overcome learning obstacles 
experienced by students related to the ability to understand mathematical concepts on material addition and subtraction of integers.

Students are not able to associate the material prerequisites to limit the problems of algebra functions. The material limit function began material closely related functions, one example is the rational functions, irrational. In addition, the material algebra operations, rationalizing the root is also closely related to the limit algebra functions. In this case, the student is not able to link the concepts of equations or these functions on the material limit. This is evidenced by the student's answers to question number 1, 2, 3, 5, and 6. Based on the students' answers on the number, students can not associate the material prerequisites to limit problems with either. This is due to students' understanding of the material is poor. Students are not able to associate the material prerequisites to limit the problems occur because students do not understand the material previously associated with the material limit. The material is a very important prerequisite for understanding the material terms of the next well. Topic or concept as a basic prerequisite for understanding the topics or concepts hereinafter. If students want to understand the material well, then he should better understand the material prerequisites again.

Students cannot write properly limit symbol occurs because students do not understand the concept of mathematical symbols. Symbol or symbol used to represent a number. According to Warsitasari (2015), student proficiency in using algebraic notation is highly dependent on their understanding of symbols. So it can be said that the students' understanding of a very important symbol in mathematics. If students are able to understand the symbols properly, then the ability of student understanding in solving the problems associated with the notation/symbols can be increased.

\section{Results Validation of Learning materials on Limit Function Material Based on Mathematical Understanding}

Designability-based learning materials are made in the form of mathematical understanding of mathematics modules. This module is based on learning difficulties experienced by students. Modules are made according to the learning objectives and stages on the theory of Jerome $\mathrm{S}$. Bruner through three stages of cognitive developments that enactive stage, the stage of the iconic and symbolic stage. The module also contains a didactic situation and anticipation of didactic to anticipate the various learning obstacles that arise. Three stages of cognitive development according to Bruner is applied to the module that stage enactive poured on sampling related to everyday life in the material limit algebraic function, phase iconic set forth in modules in the use of illustrations to instill the concept of limits, and the stage of the symbolic on the module with presented the concept of illustrations to form symbols or words.

Modules that have been prepared and then validated by four experts. The results obtained validation of $89.50 \%$, this indicates that learning materials have been prepared otherwise very valid or can be used without revision. This can be evidenced by the results of the validation every aspect, even one of the 9 aspect indicator obtain a high value, namely the aspect of completeness dish. Aspects of completeness dish obtain validation value of $93.75 \%$ with a very valid criteria. Components completeness dish consists of standards of competence, basic competence, learning indicators, table of contents, bibliography and summary. Syllabus KTSP 2006 used as a reference in selecting a standard and basic competencies. Then from the basic competence is developed further in making learning indicators in accordance with the KD. 
Table of Contents page contains related information contained in the module. While bibliography contains reference source of learning materials created.

Akbar (2013) suggested that good learning materials mentioned competencies that must be mastered readers, providing benefits to the reader the importance of mastering competencies, presents a table of contents, and presents a bibliography. Presentation of the material should be complete, systematic, grain conformity with the demands of a student-centered learning and the manner of presentation that makes easy to read and learn to cultivate students' interest and desire to learn. However, the inputs of each validator into consideration for the improvement of learning materials module. The validation results of four expert learning materials as follows.

Table 1. Results of Validation Expert

\begin{tabular}{cccc}
\hline No. & Validator & $\begin{array}{c}\text { Percentage } \\
\text { Validation }\end{array}$ & $\begin{array}{c}\text { Criteria } \\
\text { Validation }\end{array}$ \\
\hline 1 & Validator1 & $93.52 \%$ & Very Valid \\
2 & validator2 & $82.41 \%$ & Valid Enough \\
3 & Validator 3 & $92.50 \%$ & Very Valid \\
\hline
\end{tabular}

\section{Intervention Teacher In Implementation Subjects}

Student responses are given when intervening, generally, correspond to the predictions response to interventions made in accordance with the design that has been made. Intervention teachers conducted during the implementation depicted in anticipation pedagogical. The previous anticipation has been made by the teacher to solve problems beyond prediction response that does not cause learning obstacle. a new

Based on the analysis found that the situation 1 discussed on how to determine the limit of the left and right limits are assisted using a number line. Efforts that teachers do is give guidance to students to better understand the concept of the limit of the left and right limits to then conclude the answer in the form of a mathematical model related limit. Based on the results of this intervention turned out to be able to improve students' mathematical understanding that barriers to learning can be minimized.

Situation 2 discusses how to apply the limit theorem. Efforts teachers provide guidance related to the properties and remind limit theorem regarding the material prerequisites are a form of intervention teacher while learning materials are implemented. Based on the data obtained, there is a response beyond prediction that the student cannot perform arithmetic calculations division operation. The author did not expect that students will have difficulty in calculating the arithmetic division operation for long-sharing concepts students are learning arithmetic, namely when class VII even while still in elementary school. According to Sarah, Suryadi and Fatimah (2017) if the response is beyond prediction, the anticipation of pedagogical given to this response was spontaneous anticipation. One of the efforts the teachers that students are guided in the calculation of the distribution operation, the teacher guides the students to remind students about the calculation of the arithmetic properties of numbers, especially in arithmetic division operation.

Situation 3 discusses the limit symbol write correctly. Efforts teacher to give a stimulus to the students related writing the correct symbol and remind limit regarding the material 
prerequisites are a form of intervention teacher while learning materials are implemented. Based on the data obtained by the students tend according to predictions. While the situation 4 shows the results of a student's response that there is a response beyond prediction, the student is still wrong in the calculation of the concept of algebra operations. Efforts that teachers are the students reminded again of the calculation of algebraic operations.

According to Fauzi (2012), students error for understanding the concept can be minimized with the intervention of teachers based on the situation and the right time, to be reminded of such material in the form of questions that lead and dig for students to understand the concept without teacher give the final shape for granted. The teacher's role in facilitating the students when students are faced with learning difficulties in a relationship pedagogical module in accordance with one component of the didactic triangle proposed by Suryadi (2013). To encourage optimum student learning process is influenced by several things including the relationship between teachers and students (HP). The pedagogical relationship is the teacher's role in implementing the learning materials and to anticipate the response of students to the learning materials that are not in accordance with the prediction of the previous teacher.

\section{Analysis of Learning Obstacle After Implementation of Subjects}

Having implemented instructional materials, learning obstacle identified at the outset can be reduced. Learning obstacle that most greatly reduced obstacle learning students cannot write properly limit symbol. Anticipation given are anticipating anticipation didactic and pedagogical. Anticipation didactic learning materials presented in the form of problems related to limit the right of writing symbols. On these issues the student is given three options to determine the limit of writing correct, these problems are discussed with group members. The anticipation of pedagogical given when there are students / groups who are confused in determining the correct limit writing. Anticipation pedagogical provided in the form of stimulus, the stimulus-related writing teacher gives the correct symbol limit by providing questions that lead students to be able to write symbols limit properly. The question in the form of the material prerequisites (in this case is to determine the value of the function) and the concept of writing procedural limit. To cope with students who are still not able to write the limit symbols correctly, more students are expected to be able to understand more regarding the material prerequisites function, precisely in determining the value of the function (Hidayat, 2017). Rizki \& Syutaridho (2014) both concluded that the design of learning materials DDR implemented to minimize the barriers to student learning.

\section{CONCLUSION}

Based on the discussions that have been outlined, the research concluded the learning obstacle are: (a) the student can not understand the concept of limit and left limit right, (b) the student can not write symbols limit correctly, (c) students cannot apply a limit theorem, (d) the student cannot perform the procedure calculate the limit at infinity, (e) the student cannot perform factoring and determine the form of the adjacency to solve the problems limit function. Based on the results validation obtained from three validator, overall percentage of $89.50 \%$ with a very valid qualification. Intervention provided during the learning intervention limit algebraic function is didactic and pedagogical intervention. Didactic interventions that do focus on how the teaching material is presented to students by taking into account prerequisite material and the stages of learning the learning theory of Bruner, while a given pedagogical intervention focuses on how researchers deliver teaching the material to students. During the implementation of these materials more researchers using the method of group discussion. Learning obstacle experienced by students in the study of algebraic functions limit 
the material obtained from the test results about the instrument at the time of implementation. Learning obstacle after the implementation of teaching material on the material-based limit function mathematical understanding of algebra can be reduced/minimized.

\section{REFERENCES}

Akbar, S. D. (2013). Instrumen perangkat pembelajaran. Bandung: PT Remaja Rosdakarya.

Brousseau, G. (2006). Theory of didactical situations in mathematics: Didactique des mathématiques, 1970-1990 (Vol. 19). Springer Science \& Business Media.

Creswell, J. W., \& Creswell, J. D. (2017). Research design: Qualitative, quantitative, and mixed methods approaches. Sage publications.

Fauzi, K. M. A. (2012). Kemampuan Koneksi Matematis Siswa dengan Pendekatan Pembelajaran Metakognitif di Sekolah Menengah Pertama. Jurnal Paradikma, 6(1), 49-74.

Hidayat, W. (2017). Adversity Quotient dan Penalaran Kreatif Matematis Siswa SMA dalam Pembelajaran Argument Driven Inquiry pada Materi Turunan Fungsi. KALAMATIKA Jurnal Pendidikan Matematika, 2(1), 15-28.

Noto, M. S., Hartono, W., \& Sundawan, D. (2016). Analysis Of Students Mathematical Representation And Connection On Analytical Geometry Subject. Infinity Journal, 5(2), 99-108.

Ratnasari, I. (2014). Perbandingan Kemampuan Pemahaman Matematis Antara Siswa Yang Menggunakan Model Pembelajaran Problem Based Learning (Pbl) Dan Model Pembelajaran Group Investigation (Gi) Pada Siswa Kelas Viii Smp Negeri 2 Jalaksana. Euclid, 1(1).

Rizki, S., \& Syutaridho, S. (2014). Efektivitas Bahan Ajar Bangun Ruang Sisi Datar Menggunakan 5E Instructional Model terhadap Aktivitas dan Hasil Belajar. AKSIOMA: Jurnal Program Studi Pendidikan Matematika, 3(2), 1-9.

Sarah, S., Suryadi, D., \& Fatimah, S. (2017). Desain Didaktis Konsep Volume Limas pada Pembelajaran Matematika SMP berdasarkan Learning Trajectory. Journal of Mathematics Education Research, 1(1), 31-42.

Suhandri, S. (2016). Meningkatkan Kemampuan Pemahaman Matematis Siswa SMP/MTs dengan Menggunakan Strategi Konflik Kognitif. Jurnal Penelitian dan Pembelajaran Matematika, 9(2), 240-249.

Suryadi, D. (2013). Didactical Research (DDR) Dalam Mengembangkan Pembelajaran Matematika. Prosiding Seminar Nasional Pendidikan Matematika. FMIPA UNNES.

Wahyuni, I., \& Kharimah, N. I. (2017). Analisis Kemampuan Pemahaman dan Penalaran Matematis Mahasiswa Tingkat IV Materi Sistem Bilangan Kompleks pada Mata Kuliah Analisis Kompleks. JNPM (Jurnal Nasional Pendidikan Matematika), 1(2), 228-240.

Warsitasari, W. D. (2015). Berpikir Aljabar dalam Pemecahan Masalah Matematika. APOTEMA: Jurnal Program Studi Pendidikan Matematika, 1(1), 1-17. 